\title{
Fracture analysis and geometrical parameter optimization of bolted composite joints
}

\begin{abstract}
Composite materials are commonly used in structures that demand a high level of mechanical performance. Due to high strength and safety requirements, these applications require joining composites either to composites or to metals. Composite joints create highly localized stress concentration around the joints that cause failure in the substrates. The fracture toughness is the critical aspect that influence on the failure of the substrates. In this work, fracture toughness is determined for a center crack developed on the surface of the substrate of the composite joints. In FEM analysis, Stress intensity factor $(\mathrm{K})$ and $\mathrm{J}$ integral are used to find out the fracture toughness value. The influence of various parameters such as fiber orientation angle, crack length, applied load and bolt hole diameter on fracture toughness is determined with the use of LEFM in finite element analysis. Stress intensity factor and $\mathrm{J}$ integral are validated with the theoretical data available. Geometrical parameters which affect fracture toughness are optimized by using Taguchi analysis and design of experiments. The result shows that the crack length is the most significant parameter which affects the fracture toughness substantially. Elasto plastic region (dog bone shape) near the crack tip is also analyzed in this work.
\end{abstract}

Keywords: stress intensity factor (K), J integral, linear elastic fracture mechanics, fiber orientation angle
Volume 4 Issue 6 - 2020

Gobinath VK,' Manju Sri A, ${ }^{2}$ Santhosh S, ${ }^{3}$ Mugilan T, ${ }^{3}$ Moganapriya $\mathrm{C}^{3}$

'Department of Mechatronics Engineering,Anna University, India

${ }^{2}$ Department of Chemical Engineering, Anna University, India

${ }^{3}$ Department of Mechanical Engineering, Anna University, India

Correspondence: Moganapriya C,Associate Professor, Department of Mechanical Engineering, Kongu Engineering College, Anna University, Erode, Tamilnadu-638052, India, Emailmogana98@gmail.com

Received: November 24, 2020 | Published: December 31, 2020

\section{Materials and methods}

Optimal lap geometry was considered for the analysis of fracture behavior in bolted composite joints. The test specimen comprising of composite laminated upper plate, aluminums lower plate and a protruding headed bolt. ${ }^{1}$ An unidirectional fibered composite layers was considered for easier theoretical analysis. Based on nonlinear stress analysis, the selection of varying orientation especially for plies were performed. The system taken for analysis is depicted in figure and their corresponding dimensions represented in Table 1. A input file was initially created through ANSYS code for the creation of 3D model as specified before for simulation purpose. ${ }^{2}$ Meshing was done before analyzing the 3D model. The 8-noded SOLID46 3-D ANSYS element was considered for modeling of required 3D model which is constrained in all directions. Basic 2D sketch of 3D object is depicted in Figure 1. With the usage of SOLID45 3-D ANSYS element, the modelling of composite plate and bolt was done. The contact between the surfaces in the required model were established through 3-D CONTAC49 ANSYS element. The properties of composite material in various directions are tabulated in Table 2.

Table I Dimensions of the composite plate $(\mathrm{mm})$

\begin{tabular}{lllllll}
\hline $\mathrm{L}$ & $\mathrm{W}$ & $\mathrm{D}$ & $\mathrm{d}$ & $\mathrm{e}$ & $\mathrm{h}$ & $\mathrm{t}$ \\
240 & 60 & 16 & 10 & 30 & 30 & 4.16 \\
\hline
\end{tabular}

Table 2 Properties of composite material

\begin{tabular}{|c|c|c|c|c|c|c|c|c|}
\hline $\begin{array}{l}\mathbf{E}_{\mathbf{X}} \\
(\mathbf{G P a})\end{array}$ & $\begin{array}{l}E_{Y} \\
(\mathbf{G P a})\end{array}$ & $\begin{array}{l}E_{\mathrm{z}} \\
(\mathrm{GPa})\end{array}$ & $\begin{array}{l}\mathbf{G}_{X Y} \\
(\mathbf{G P a})\end{array}$ & $\begin{array}{l}\mathbf{G}_{x z} \\
(\mathbf{G P a})\end{array}$ & $\begin{array}{l}\mathbf{G}_{\mathrm{YZ}} \\
(\mathrm{GPa})\end{array}$ & $\mu_{X Y}$ & $\boldsymbol{\mu}_{\mathrm{xz}}$ & $\boldsymbol{\mu}_{\mathrm{yz}}$ \\
\hline 145 & 10.3 & 12.1 & 5.3 & 5.275 & 3.95 & 0.301 & 0.5 & 0.495 \\
\hline
\end{tabular}

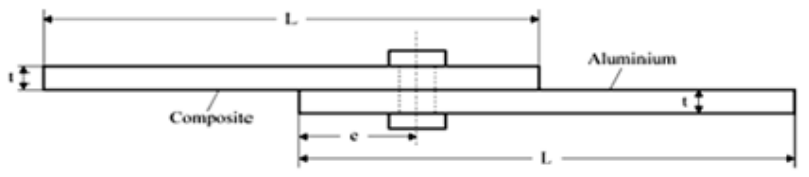

Nonlinear stress analysis was performed for the load of $12 \mathrm{kN}$. One end of the Aluminum joint is fixed and the load is applied on the free end of the composite beam. Secondary bending of the joint was prevented by applying lateral support i.e. zero displacement in the z-direction in the model. Mesh model of the joints is developed through ANSYS 12 and shown in the figure Stress and strains are calculated for different fiber orientation angles as given in the figure. $90^{\circ}$ orientation fibers are aligned in the direction of applied load. It shows that the strength of the fiber is very high in the loading direction i.e. $90^{\circ}$ fiber orientation ${ }^{3}$ the value of stress varies for

Figure I Geometry of the bolted single-lap joint. 
the value of stress is minimum. The bridging occur only in the fibers arranged other than 0 degree orientation, while other than 0 degree orientation bridging occurs and seemed to be rough in nature. ${ }^{4}$ The unpredictable shifting of crack is mainly noticed in (90/45//45/90) specimen. Easier crack shifting mechanisms can be facilitated through alternating 45 and 90 degree oriented composite plies. For opposite oriented alternate 45 degree plies, shifting of crack mechanisms can be much more difficult. ${ }^{5}$ The plot against max and Von mises stress Vs layer orientation represented in Figure 2. The effect of applied load on layer orientation indicated in Table. $3.90^{\circ}$ orientation fibers are aligned in the direction of applied load. Generally the strength is maximum in the direction of applied load. So the $90^{\circ}$ orientation produces minimum stress and it is best suited for the analysis. ${ }^{6}$ From the nonlinear stress analysis, the layer orientation which has minimum stress is $[90 / 0 /-45 / 45]^{\circ} \mathrm{S} 8$ with the stress value of $352.229 \mathrm{MPa}$ and is taken for the crack analysis of the composite joints. The stacking of various layers with selected layer orientation is shown in the Figure 3. The high stress region is shown as Mx in the figure and the crack is introduced in that region.
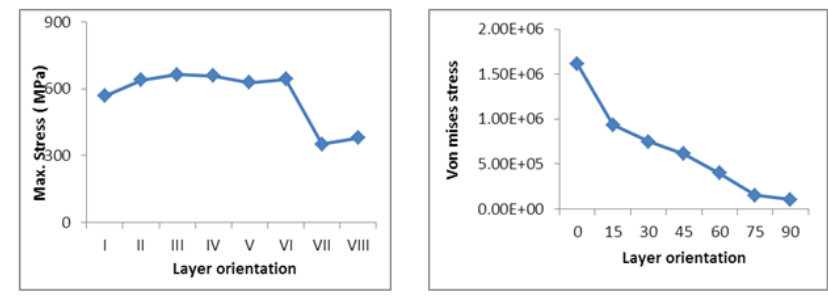

Figure 2 Stress developed for different layer orientation.

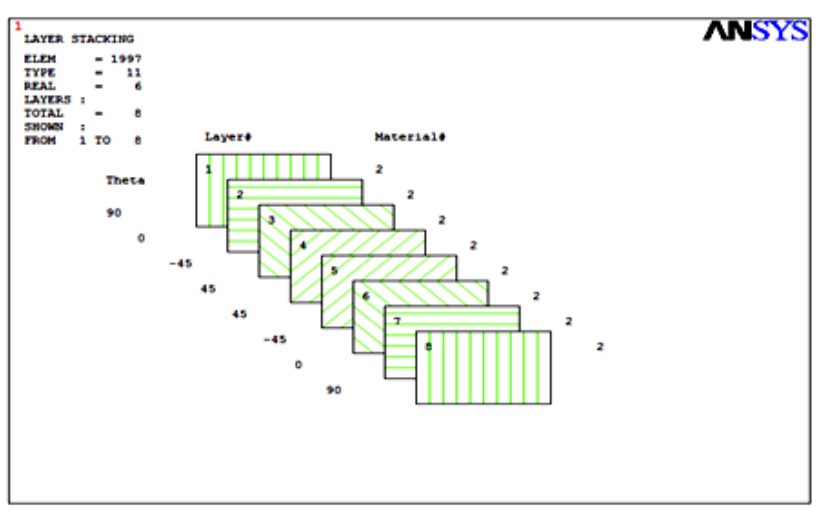

Figure 3 Layer stacking sequence.

Table 3 Effect of layer orientation on the applied load

\begin{tabular}{lll}
\hline S.No & Layer orientation & Maximum stress $(\mathbf{M P a})$ \\
\hline $\mathrm{I}$ & {$[0 / 15 / 15 / 0]^{\circ}$ S8 } & 567.486 \\
2 & {$[0 / 30 / 30 / 0]^{\circ}$ S8 } & 640.23 \\
3 & {$[0 / 45 / 45 / 0]^{\circ}$ S8 } & 664.083 \\
4 & {$[0 / 60 / 60 / 0]^{\circ}$ S8 } & 659.144 \\
5 & {$[0 / 75 / 75 / 0]^{\circ}$ S8 } & 627.828 \\
6 & {$[0 / 90 / 90 / 0]^{\circ}$ S8 } & 643.912 \\
7 & {$[90 / 0 /-45 / 45]^{\circ}$ S8 } & 352.229 \\
8 & {$[-45 / 45 /-45 / 45]^{\circ}$ S8 } & 378.777 \\
\hline
\end{tabular}

\section{Crack analysis of bolted joints}

Crack of $10 \mathrm{~mm}$ length is induced in the high stress region shown in the figure of the selected orientation of the bolted joints. Nonlinear stress analysis report is portrayed in Figure 4. Because of the symmetry of the joint, only quadrant of the joint is considered for the analysis as shown in figure. Fracture toughness can be determined by $\mathrm{J}$ integral approach in ANSYS. Because of symmetry, a one-quarter model is used for calculating fracture parameters. Hence occurred crack model, J-integral calculation and stress intensity calculation using calculated J-integral. The crack propagation and the plastic zone near the crack tip are shown in Figure 5.

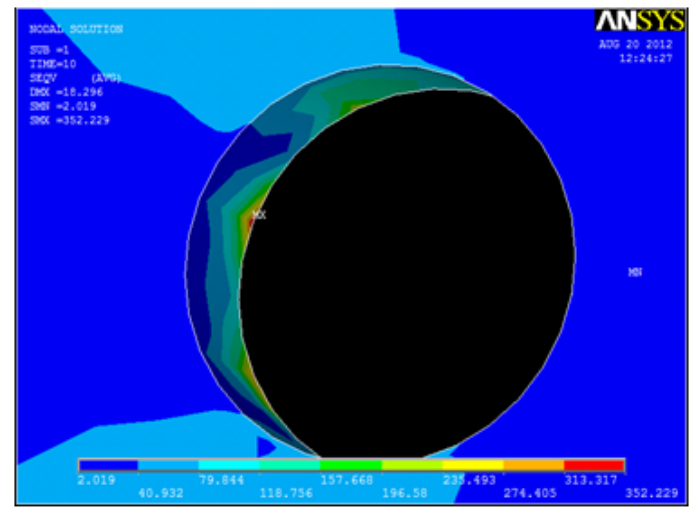

Figure 4 Nonlinear stress analysis.
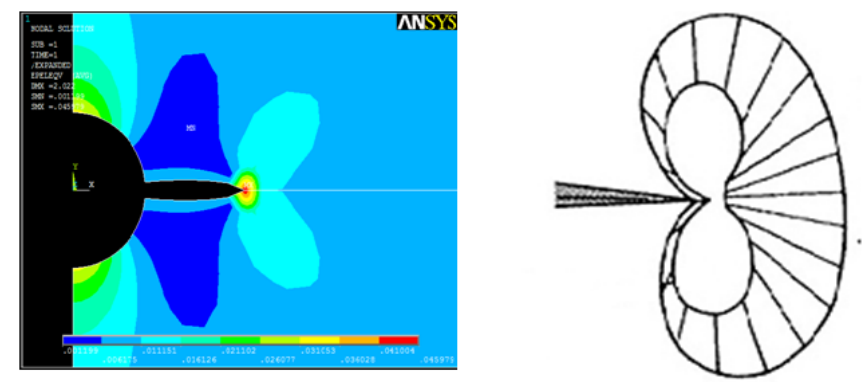

Figure 5 Crack propagation through the material.

\section{Effect of crack length on stress intensity factor and J integral}

Crack of $5 \mathrm{~mm}$ length is introduced in the top surface of the hole which has the maximum von misses stress value. ${ }^{7}$ The corresponding value of the stress intensity factor and $\mathrm{J}$ integral is determined. The crack length is varied from $5 \mathrm{~mm}$ to 15 gradually and the significant effect on the stress intensity factor and $\mathrm{J}$ integral is represented as plotted graphs in Figure 6. The effect of varying crack length on stress intensity factor and $\mathrm{j}$ integral are validated with the theoretical data calculated. The crack length of $6 \mathrm{~mm}$ and $7 \mathrm{~mm}$ has the ill conditions, because of that there is a slight deviation in the stress intensity factor and $\mathrm{j}$ integral at the two points. But at the crack length of 6.2 and $7.2 \mathrm{~mm}$ the curve coincides with the theoretical value. The average error percentage is calculated and is found to be $3.54 \%$ for stress intensity factor and $5.92 \%$ for $\mathrm{j}$ integral.

\section{Effect of applied load on stress intensity factor and J integral}

With the Crack of $5 \mathrm{~mm}$ length, the load is applied on the free end of the composite plate. The load is varied from $8 \mathrm{kN}$ to $15 \mathrm{kN}$. The corresponding value of the stress intensity factor and $\mathrm{J}$ integral is determined for different load values. The significant effect on the stress intensity factor and $\mathrm{J}$ integral is represented as plotted graphs in 
Figure 7. The stress intensity factor and $\mathrm{j}$ integral varies very linearly with the applied load. The values are validated with the theoretical data available. The average error percentage is calculated and is found to be $0.408 \%$ for stress intensity factor and $0.816 \%$ for $\mathrm{j}$ integral.

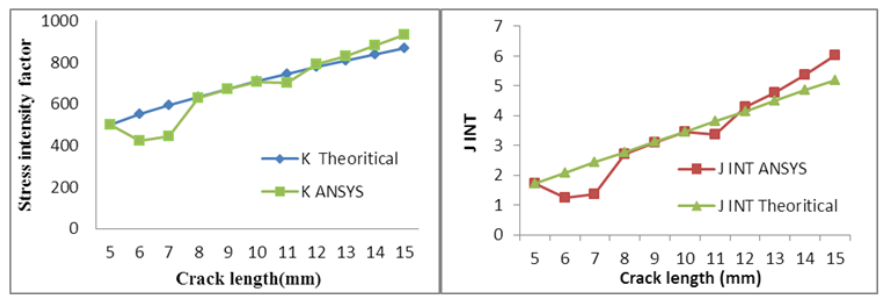

Figure 6 Effect of crack length on stress intensity factor and J integral.

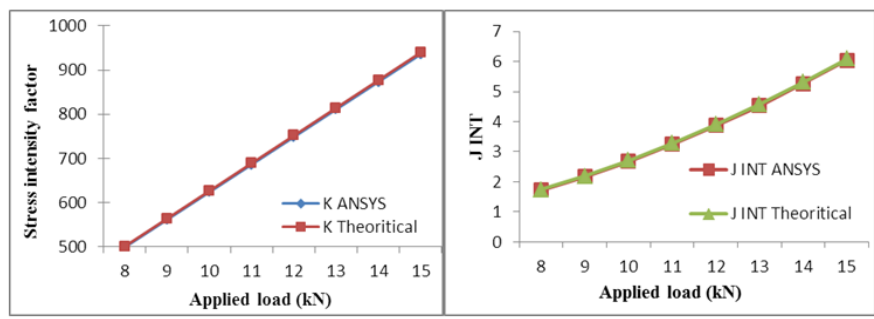

Figure 7 Effect of applied load on stress intensity factor and J integral.

\section{Geometrical parameter optimization of bolted joints}

\section{Taguchi experiment: design and analysis}

In general, traditional experimental design were been complicated hence there is need of adopting alternate analysis method for finding best optimal results. For increased experimentation trials number of process parameters might also be increased. ${ }^{6,8}$ The simple solution for this problem is Taguchi method which creates orthogonal array design especially for smaller number of experiments. It is used at most of the cases regarding single objective function, and one output parameter based experiments can be easily analyzed. ${ }^{9,10}$ Also multi objective function if converted into equivalent single objective function, then those problems can also be analyzed through Taguchi method. Some of the advantages of this method are reduced overall cost, minimal experimental analysis, easier detection of optimal solution and reducing experimental time. ${ }^{11}$ Three major design in product and process development are tolerance, parameter and system design. The basic configuration which is obtained through application of basic scientific principles through system design. ${ }^{22}$ The determination of specified process parameter values through parameter design. The best optimal tolerances of experimental process parameters can be defined through tolerance design..$^{13,14}$ The individual weightage of process parameters can be determined through overall effect of $\mathrm{S} / \mathrm{N}$ ratio. Various steps involved in Taguchi technique are depicted in Figure 8 .

\section{Plan of experiments}

Through the combined effect of experiment design theory and quality loss function, Taguchi technique helps to develop the robust process and product designs. ${ }^{2,12}$ An array comprising of 4 columns and 16 rows which represents the significant levels and corresponding number of tests as specified in Table 2. The major influencing parameter for crack propagation is stress intensity factor $(R a)$. Five influential parameters such as bolt hole diameter, applied load, edge to bolt hole diameter, width to bolt hole diameter and crack length at four levels were considered for Taguchi analysis which were tabulated in Table 4 $\&$ Table 5. The effect of stress intensity factor responsible for failure was determined through tabulated parameters and corresponding values for obtaining the optimal value of parameter. ${ }^{12,13}$

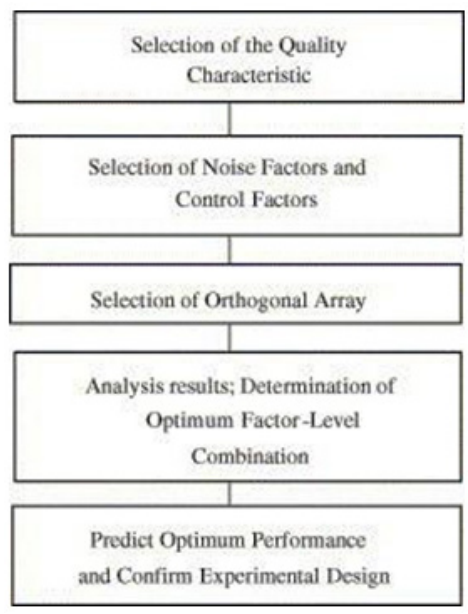

Figure 8 Steps in Taguchi optimization.

\section{Data analysis and results}

\section{Analysis of the $\mathbf{S} / \mathbf{N}$ ratio}

The desirable and undesirable value for the output characteristics were known as signal and noise in Taguchi method. Mathematically signal and noise were known as mean and standard deviation of obtained experimental results. ${ }^{15,16}$ It is a measure of characteristic quality of deviation from desired value. Depending on the required results, $\mathrm{S} / \mathrm{N}$ ratios were classified as lower is better (LB), nominal is best (NB), or higher is better (HB). The smaller is better can be confirmed through:

$$
\mathrm{S} / \mathrm{N}=-10 * \log _{10}\left(\operatorname{sum}\left(\mathrm{Y}^{* * 2}\right) / \mathrm{n}\right)
$$

where $n=$ number of trials, for instance $n=4$ and $y_{i}$ is the $i^{\text {th }}$ measured value in row. The measured $\mathrm{Ra}$ and $\mathrm{S} / \mathrm{N}$ ratio values are collectively tabulated in Table 6 . The $\mathrm{S} / \mathrm{N}$ response results and process parameters were been indicated in Table 7 . The optimized process parameters were diagrammatically represented in Figure 9.

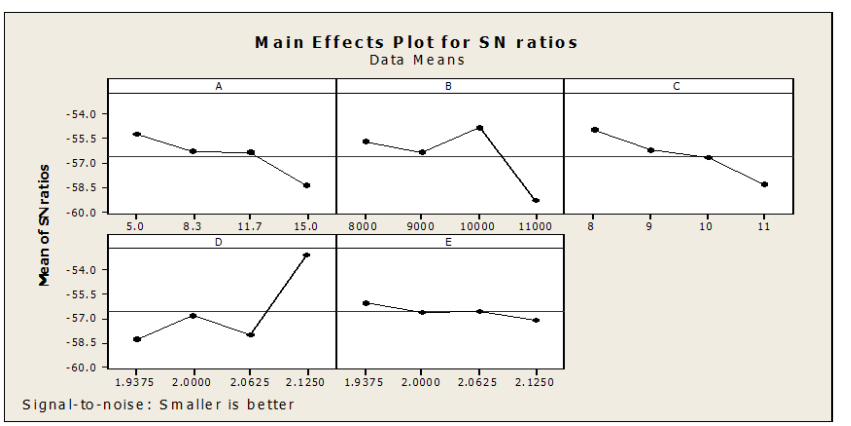

Figure 9 The effects of process parameters $(\mathrm{S} / \mathrm{N}$ response table for stress intensity factor).

\section{Analysis of variance (Anova)}

ANOVA was initially devised for the interpreting the results of agricultural experiments. It is the statistical tool used for the detection 
of any variations in average performances of test specimen selected among the similar population. ${ }^{17}$ ANOVA helps in formally testing the significance of all main factors and their interactions by comparing the mean square against an estimate of the experimental errors at specific confidence levels. This is variability of the $\mathrm{S} / \mathrm{N}$ ratios, which is measured by the sum of the squared deviations from the total mean $\mathrm{S} / \mathrm{N}$ ratio, into contributions by each of the design parameters and the error. ${ }^{18}$ First, the total sum of squared deviations SST from the total mean $\mathrm{S} / \mathrm{N}$ ratio $\eta_{\mathrm{m}}$ can be calculated as:

$$
\mathrm{SS}_{\mathrm{T}}=\sum_{i=1}^{n}(\eta i-\eta m) 2
$$

where $\mathrm{n}$ is the number of experiments in the orthogonal array and $\eta \mathrm{i}$ is the mean $\mathrm{S} / \mathrm{N}$ ratio for the ith experiment. The percentage contribution $\mathrm{P}$ can be calculated as below:

Table 4 The process parameters and their levels

$$
\mathrm{P}=\mathrm{SS}_{\mathrm{d}} / \mathrm{SS}_{\mathrm{T}}
$$

where $\mathrm{SS}_{\mathrm{d}}$ is the sum of squared deviations. F-test used to find out which of the design parameters hold better significant effect over the quality characteristics. $F$ ratio corresponds to $95 \%$ confidence level in evaluation of accurate process parameters is $F 0.05,2,26=3.37$. In Table 8, the significance level of $P$ value were consolidated. ${ }^{19}$ The rate of significant process parameters on $\mathrm{Ra}$ is known as Percent (\%). It can observed from Table 8 that Significant percent of process parameters such as crack length (A), applied load (B), bolt hole diameter (C), edge to bolt hole diameter (D), width to bolt hole diameter (E) affect stress intensity factor were observed in Table 8 as $17.88 \%, 38.27 \%$, $20.14 \%$ and $23.69 \%$. Because of $F>F \alpha=5 \%$, the process parameters present statistical and physical significance on Stress intensity factor, because Test as shown in Table 8 .

\begin{tabular}{llllll}
\hline Sample & Parameters & Level I & Level 2 & Level 3 & Level 4 \\
\hline A & Crack length $(\mathrm{mm})$ & 5 & 8.3 & 11.7 & 15 \\
B & Applied load $(\mathrm{kN})$ & 8000 & 9000 & 10000 & 11000 \\
C & Bolt hole diameter $(\mathrm{mm})$ & 8 & 9 & 10 & $1 \mathrm{I}$ \\
D & Edge/bolt hole diameter & 1.9375 & 2.000 & 2.0625 & 2.1250 \\
E & Width/bolt hole diameter & 1.9375 & 2.000 & 2.0625 & 2.1250 \\
\hline
\end{tabular}

\begin{tabular}{|c|c|c|c|c|c|c|}
\hline S. No & Designation & $\begin{array}{l}\text { A } \\
\text { Crack length } \\
(\mathrm{mm})\end{array}$ & $\begin{array}{l}\text { B } \\
\text { Applied load } \\
\text { (kN) }\end{array}$ & $\begin{array}{l}\text { C } \\
\text { Bolt hole } \\
\text { diameter }(\mathrm{mm})\end{array}$ & $\begin{array}{l}\text { D } \\
\text { Edge/bolt hole } \\
\text { diameter }\end{array}$ & $\begin{array}{l}\text { E } \\
\text { Width/bolt hole } \\
\text { diameter }\end{array}$ \\
\hline 1 & $A_{1} B_{1} C_{1} D_{1} E_{1}$ & 1 & I & 1 & 1 & 1 \\
\hline 2 & $\mathrm{~A}_{1} \mathrm{~B}_{2} \mathrm{C}_{2} \mathrm{D}_{2} \mathrm{E}_{2}$ & I & 2 & 2 & 2 & 2 \\
\hline 3 & $A_{1} B_{3} C_{3} D_{3} E_{3}$ & I & 3 & 3 & 3 & 3 \\
\hline 4 & $\mathrm{~A}_{1} \mathrm{~B}_{4} \mathrm{C}_{4} \mathrm{D}_{4} \mathrm{E}_{4}$ & I & 4 & 4 & 4 & 4 \\
\hline 5 & $\mathrm{~A}_{2} \mathrm{~B}_{1} \mathrm{C}_{2} \mathrm{D}_{3} \mathrm{E}_{4}$ & 2 & 1 & 2 & 3 & 4 \\
\hline 6 & $\mathrm{~A}_{2} \mathrm{~B}_{2} \mathrm{C}_{1} \mathrm{D}_{4} \mathrm{E}_{3}$ & 2 & 2 & 1 & 4 & 3 \\
\hline 7 & $\mathrm{~A}_{2} \mathrm{~B}_{3} \mathrm{C}_{4} \mathrm{D}_{1} \mathrm{E}_{2}$ & 2 & 3 & 4 & I & 2 \\
\hline 8 & $\mathrm{~A}_{2} \mathrm{~B}_{4} \mathrm{C}_{3} \mathrm{D}_{2} \mathrm{E}_{1}$ & 2 & 4 & 3 & 2 & I \\
\hline 9 & $\mathrm{~A}_{3} \mathrm{~B}_{1} \mathrm{C}_{3} \mathrm{D}_{4} \mathrm{E}_{2}$ & 3 & 1 & 3 & 4 & 2 \\
\hline 10 & $\mathrm{~A}_{3} \mathrm{~B}_{2} \mathrm{C}_{4} \mathrm{D}_{3} \mathrm{E}_{1}$ & 3 & 2 & 4 & 3 & I \\
\hline II & $\mathrm{A}_{3} \mathrm{~B}_{3} \mathrm{C}_{1} \mathrm{D}_{2} \mathrm{E}_{4}$ & 3 & 3 & 1 & 2 & 4 \\
\hline 12 & $\mathrm{~A}_{3} \mathrm{~B}_{4} \mathrm{C}_{2} \mathrm{D}_{1} \mathrm{E}_{3}$ & 3 & 4 & 2 & 1 & 3 \\
\hline 13 & $\mathrm{~A}_{4} \mathrm{~B}_{1} \mathrm{C}_{4} \mathrm{D}_{2} \mathrm{E}_{3}$ & 4 & I & 4 & 2 & 3 \\
\hline 14 & $A_{4} B_{2} C_{3} D_{1} E_{4}$ & 4 & 2 & 3 & 1 & 4 \\
\hline 15 & $\mathrm{~A}_{4} \mathrm{~B}_{3} \mathrm{C}_{2} \mathrm{D}_{4} \mathrm{E}_{1}$ & 4 & 3 & 2 & 4 & I \\
\hline 16 & $\mathrm{~A}_{4} \mathrm{~B}_{4} \mathrm{C}_{1} \mathrm{D}_{3} \mathrm{E}_{2}$ & 4 & 4 & I & 3 & 2 \\
\hline
\end{tabular}

Table 5 An orthogonal array LI6 (4*5) of Taguchi

Table 6 Ra and S/N ratio values

\begin{tabular}{lll}
\hline $\begin{array}{l}\text { Experiment } \\
\text { numbers }\end{array}$ & $\begin{array}{l}\text { Stress intensity } \\
\text { factor value }(\mathrm{Ra})\end{array}$ & $\begin{array}{l}\text { S/N ratio } \\
(\mathbf{d B})\end{array}$ \\
\hline 1 & 499.52 & -53.9711 \\
2 & 564.32 & -55.0305 \\
3 & 566.78 & -55.0683 \\
4 & 695.84 & -56.8502 \\
5 & 717.40 & -57.1152 \\
6 & 352.78 & -50.9501 \\
7 & 808.45 & -58.1531 \\
\hline
\end{tabular}

\begin{tabular}{lll}
\hline $\begin{array}{l}\text { Experiment } \\
\text { numbers }\end{array}$ & $\begin{array}{l}\text { Stress intensity } \\
\text { factor value }(\mathbf{R a})\end{array}$ & $\begin{array}{l}\mathbf{S} / \mathbf{N} \text { ratio } \\
(\mathbf{d B})\end{array}$ \\
\hline 8 & 881.09 & -58.9004 \\
9 & 409.99 & -52.2555 \\
\hline 10 & 880.52 & -58.8948 \\
11 & 490.74 & -53.8170 \\
12 & 1066.40 & -60.5584 \\
13 & 956.79 & -59.6163 \\
14 & 1065.80 & -60.5535 \\
15 & 413.24 & -52.3240 \\
16 & 1136.70 & -61.1129 \\
\hline
\end{tabular}


Table 7 S/N response table for stress intensity factor

\begin{tabular}{llllll}
\hline Level & A & B & C & D & E \\
\hline I & -55.23 & -55.74 & -54.96 & -58.3 I & -56.02 \\
2 & -56.28 & -56.36 & -56.26 & -56.84 & -56.64 \\
3 & -56.38 & -54.84 & -56.69 & -58.05 & -56.55 \\
4 & -58.40 & -59.36 & -58.38 & -53.09 & -57.08 \\
Delta & 3.17 & 4.51 & 3.42 & 5.21 & 1.06 \\
Rank & 4 & 2 & 3 & I & 5 \\
\hline
\end{tabular}

Table 8 ANOVA results for stress intensity factor

\begin{tabular}{|c|c|c|c|c|c|c|}
\hline $\begin{array}{l}\text { Source of } \\
\text { variation }\end{array}$ & $\begin{array}{l}\text { Degrees of } \\
\text { freedom (DOF) }\end{array}$ & $\begin{array}{l}\text { Sum of squares } \\
\text { (SOS) }\end{array}$ & MS & $\begin{array}{l}\text { F ratio } \\
\text { F }\end{array}$ & $\begin{array}{l}\text { P Value } \\
\text { P }\end{array}$ & $\begin{array}{l}\text { Contribution } \\
\text { P\% }\end{array}$ \\
\hline Model & 116.66 & 12 & 9.72 & 0.63 & 0.0433 & significant \\
\hline C-C & 23.87 & 3 & 7.96 & 0.52 & 0.006978 & $38.27 \%$ \\
\hline Residual & 45.94 & 3 & $|5.3|$ & & & $100 \%$ \\
\hline
\end{tabular}

\section{C. confirmation tests}

In parameter design, confirmation test plays a vital role which reveals the best suitable parameters. With the utilization of levels of optimized process parameters $\left(\mathrm{A}_{1} \mathrm{~B}_{3} \mathrm{C}_{1} \mathrm{D}_{4} \mathrm{E}_{1}\right)$, a confirmation experiments were conducted for part experiments. The main role of confirmation experiment is to validate the optimal cutting parameters to run the experiments which corresponds with the predicted values.

\section{Conclusion}

The detailed literature survey related to fracture mechanics, composite joints, J integral was performed. Stress analysis for different fiber orientation was carried out and from that suitable layer was selected. Then the crack region is analyzed by $\mathrm{J}$ integral method. The value of $\mathrm{K}$ and $\mathrm{J}$ for the selected path is calculated from the ANSYS results. The plastic zone near the crack tip and the crack propagation is clearly analyzed and compared with the available data from the literature. The effect of various parameters such as loading conditions, crack length on the fracture toughness were determined and correlated with the theoretical data. The average error is found to be $3.54 \%, 5.92 \%, 0.41 \%$ and $0.82 \%$ for crack length on $\mathrm{K}$ and $\mathrm{J}$ Int, applied load on $\mathrm{K}$ and $\mathrm{J}$ Int respectively. The parameters affecting the fracture toughness were optimized using Taguchi method and the best optimal settings for the parameters are found to be A1B3C1D4E1. The optimum value for crack length is $5 \mathrm{~mm}$, for applied load is $10000 \mathrm{kN}$, for bolt hole diameter is $8 \mathrm{~mm}$, for edge to bolt hole diameter is 2.125 and for width to bolt hole diameter is 1.9375 . The ANOVA result shows that the crack length is the most significant parameter which affects the fracture toughness substantially by $31 \%$.

\section{Acknowledgements}

None.

\section{Conflicts of interest}

The authors declare that there is no conflict of interest.

\section{References}

1. Ayyar M, Mani MP, Jaganathan SK, et al. Preparation, characterization and blood compatibility assessment of a novel electrospun nanocomposite comprising polyurethane and ayurvedic-indhulekha oil for tissue engineering applications. Biomedical Engineering/Biomedizinische Technik. 2018;63(3):245-253.

2. Chinnasamy M, Rathanasamy R, Kannayiram P, et al. Experimental investigation on the effect of multilayer TiCN/TiAlN/WC-C coating on the tribological behaviour of tool inserts for machining applications. International Journal of Materials Engineering Innovation. 2019;10(3):186-202.

3. Jaganathan SK, Mani MP, Palaniappan SK, et al. Fabrication and characterisation of nanofibrous polyurethane scaffold incorporated with corn and neem oil using single stage electrospinning technique for bone tissue engineering applications. Journal of Polymer Research. 2018;25(7):146.

4. Chinnusamy S, Ramasamy V, Venkatajalapathy S, et al. Experimental investigation on the effect of ceramic coating on the wear resistance of Al6061 substrate. Journal of Materials Research and Technology. 2019;8(6):6125-6133.

5. Kaliyannan GV, Kumar PS, Kumar SM, et al. Mechanical and tribological behavior of $\mathrm{SiC}$ and fly ash reinforced $\mathrm{Al} 7075$ composites compared to SAE 65 bronze. Materials Testing. 2018;60(12):1225-1231.

6. Kaliyannan GV, Palanisamy SV, Palanisamy M, et al. Utilization of 2D gahnite nanosheets as highly conductive, transparent and light trapping front contact for silicon solar cells. Applied Nanoscience. 2019;9(7):1427-1437.

7. Moganapriya CR, Rajasekar PS, Kumar T, et al. Achieving machining effectiveness for AISI 1015 structural steel through coated inserts and grey-fuzzy coupled Taguchi optimization approach. Structural and Multidisciplinary Optimization. 2020:1-18.

8. Ramakrishnan S, Krishnamurthy K, Rajasekar R, et al. An experimental study on the effect of nano-clay addition on mechanical and water absorption behaviour of jute fibre reinforced epoxy composites. Journal of Industrial Textiles. 2019;49(5):597-620. 
9. Kaliyannan GV, Palanisamy SV, Subramanian M, et al. Development of sol-gel derived gahnite anti-reflection coating for augmenting the power conversion efficiency of polycrystalline silicon solar cells. Materials Science-Poland. 2019;37(3):465-472.

10. Rajasekar R, Pranavkarthik K, Prashanth R, et al. Design and fabrication of staircase climbing wheelchair. Int J Mech Eng \& Rob Res. 2013.

11. Rajasekar R, Nayak G, Malas A, et al. Development of compatibilized SBR and EPR nanocomposites containing dual filler system. Materials \& Design. 2012;35:878-885.

12. Moganapriya C, Rajasekar R, Ponappa K, et al. Influence of coating material and cutting parameters on surface roughness and material removal rate in turning process using Taguchi method. Materials Today: Proceedings. 2018;5(2):8532-8538.

13. Kaliyannan GV, Palanisamy SV, Priyanka E, et al. Investigation on solgel based coatings application in energy sector-A review. Materials Today: Proceedings. 2020.

14. Ramasamy D, Subramanian MK, Kaliyannan GV, et al. Tribomechanical behavior of B4Cp reinforced Al 359 composites. Materials Testing. 2017;59(2):172-177.
15. Kaliyannan GV, Palanisamy SV, Rathanasamy $R$, et al. Influence of ultrathin gahnite anti-reflection coating on the power conversion efficiency of polycrystalline silicon solar cell. Journal of Materials Science: Materials in Electronics. 2020;31(3):2308-2319.

16. Nayak GC, Sahoo S, Rajasekar R, et al. Novel approach for the selective dispersion of MWCNTs in the Nylon/SAN blend system. Composites Part A: Applied Science and Manufacturing. 2012.43(8):1242-1251.

17. Khoshravan M, Mehrabadi FA. Fracture analysis in adhesive composite material/aluminum joints under mode-I loading; experimental and numerical approaches. International journal of adhesion and adhesives. 2012;39:8-14.

18. Elamin M, Li B, Tan KT. Impact Performance of Stitched and Unstitched Composites in Extreme Low Temperature Arctic Conditions. Journal of Dynamic Behavior of Materials. 2018;4(3):317-327.

19. Stickler PB, Ramulu M, Johnson PS. Experimental and numerical analysis of transverse stitched T-joints in bending. Composite Structures. 2000;50(1):17-27. 